\title{
PENGARUH DURASI PENGGUNAAN GADGET TERHADAP MASALAH MENTAL EMOSIONAL ANAK PRA SEKOLAH DI TK PEMBINA KOTA TEGAL
}

\author{
Adevia Maulidya Chikmah', Desy Fitrianingsih ${ }^{2}$ \\ E-mail: depheeya@gmail.com \\ ${ }^{1,2}$ Program Studi DIII Kebidanan, Politeknik Harapan Bersama Tegal, Indonesia \\ Jln. Mataram No.09 Tegal \\ Telp/Fax (0283)352000
}

\begin{abstract}
Abstrak
$8,1 \%$ balita mengalami gangguan masalah mental emosional (perkembangan) dan $1,92 \%$ anak usia sekolah menyandang retardasi mental. 16\% Balita Indonesia mengalami gangguan perkembangan, yang meliputi sosial kemandirian, perkembangan motorik kasar dan halus dan kecerdasan kurang (Depkes RI, 2014). Sedangkan pada Tahun 2014 angka cakupan SDIDTK anak balita dan anak prasekolah tingkat Jawa Tengah sebesar 53,44 \%. Pada saat ini kita mempunyai permasalahan yaitu pemberian gadget yang terlalu dini di era globalisasi yang dapat menyebabkan hal negatif terhadap perkembangan balita. Tujuannya adalah Untuk mengetahui Pengaruh Durasi Penggunaan Gadget Terhadap Masalah Mental Emosional Pada Anak Pra Sekolah di TK Pembina Kota Tegal Tahun 2016. Jenis penelitian ini survei analitik, dengan rancangan penelitian observasional dengan pendekatan prospektif. Responden yang diteliti adalah anak usia 3-6 tahun, dengan jumlah 71 responden. Analisis yang digunakan adalah Man Whitney. Hasil penelitian ini menunjukkan "ada pengaruh antara durasi penggunaan gadget dengan Masalah Mental Emosional pada anak pra sekolah di TK Negeri Pembina Kota Tegal”.
\end{abstract}

Kata Kunci: Gadget, Masalah Mental Emosional, Anak Pra Sekolah.

\section{Pendahuluan}

Berdasarkan survei Asosiasi Penyelenggara Jasa Internet Indonesia (APJII) pada tahun 2014, pengaksesan internet paling banyak dilakukan melalui Smartphone, yaitu sebesar $70,1 \%$, personal notebook $45,4 \%$, PC rumah $41 \%$, personal netbook $5,6 \%$, tablet $3,4 \%$, dan sisanya tidak memiliki perangkat pribadi sebanyak $1,3 \%{ }^{[1]}$.

Penelitian yang dipimpin oleh Dr. Cathy Williams dan Dr. Jes Gunggenheim mengatakan bahwa anak yang sering mengguakan gadget dapat menyebabkan terjadi kesenjangan dalam bermasyarakat. Pemberian gadget yang terlalu dini dapat menyebabkan dampak negatif terhadap perkembangan Balita ${ }^{[2]}$.

Permasalahan yang terjadi pada generasi saat ini adalah banyak anak mulai kecanduan gadget yang berdampak psikologis terutama krisis percaya diri, juga pada perkembangan fisik anak yang lupa bersosialisasi dengan lingkungan sekitarnya ${ }^{[3]}$.

Frekuensi penggunaan Gadget sangat memengaruhi perilaku komunikasi individu. Kini gadget sudah menjadi media komunikasi pokok. Hal tersebut bisa dibuktikan dengan kenyataan di lapangan, semua orang pasti tidak bisa lepas dari gadget, baik dalam berkomunikasi ataupun sekadar mengunggah di media sosial. Hal tersebut memperlihatkan bahwa intensitas penggunaan gadget berpengaruh terhadap perubahan perilaku individu ${ }^{[4]}$.

Berdasarkan hasil penelitian bahwa apabila orang tua membiarkan anak menggunakan aplikasi gadget yang terlalu lama akan menjadikan anak tersebut menjadi tidak konsentrasi atau malas belajar, dan menurunkan kualitas anak dalam bersosialisasi karena penggunaan gadget yang tidak seimbang dengan efesien penggunaannya ${ }^{[5]}$.

Menurut WHO tahun 2013 mencapai 8,1 $\%$ balita mengalami gangguan perkembangan, dan 1,92\% anak usia sekolah menyandang retardasi mental. Berdasarkan Depkes RI, 2014 bahwa 16\% Balita Indonesia mengalami gangguan perkembangan $^{[6]}$.

Menurut Dinas Kesehatan Provinsi Jawa Tengah tahun 2014, angka cakupan SDIDTK anak balita dan prasekolah tingkat Jawa Tengah pada sebesar 53,44 \%. Angka cakupan tersebut lebih rendah apabila 
dibandingkan pada tahun 2013 yaitu sebesar $65 \%{ }^{[6]}$.

Pada masa Balita perlu dilakukan optimalisasi untuk merangsang perkembangan karena masa ini adalah golden age. Perkembangan psikososial merupakan hal yang penting untuk dimiliki anak. Orang tua diharapkan dapat membimbing dan mengawasi anak-anaknya dalam menggunakan gadget. Sehingga anakanak dapat mengerti hal apa saja yang termasuk hal yang baik dan yang tidak ${ }^{[7]}$.

Menjadi pribadi yang matang, bertanggung jawab, dan mandiri dalam kehidupannya, maka perlu dilakukan pembentukan pribadi anak secara dini. Hal ini disebabkan Anak usia 4-6 tahun adalah masa usia emas, dimana dimulai pembentukan kepribadian anak.

Berdasarkan uraian diatas peneliti tertarik melakukan penelitian dengan judul "Pengaruh Durasi Penggunaan Gadget Terhadap Masalah Mental Emosional Pada Anak Pra Sekolah di TK Pembina Kota Tegal Tahun 2016".

Tujuan penelitian ini adalah Untuk mengetahui Pengaruh Durasi Penggunaan Gadget Terhadap Masalah Mental Emosional Pada Anak Pra Sekolah di TK Pembina Kota Tegal Tahun 2016.

\section{Metode Penelitian}

Rancangan penelitian yang digunakan adalah observasional dengan pendekatan prospektif. Rancangan Prospektif merupakan rancangan penelitian yang digunakan untuk mempelajari dinamika kolerasi antara faktor risiko dengan efek melalui pendekatan longitudinal ke depan ${ }^{[8]}$.

Jenis penelitian ini adalah survei analitik yaitu survei atau penelitian yang mencoba menggali fenomena kesehatan itu bisa terjadi.

Populasi dalam penelitian ini adalah Balita usia 3-6 tahun di TK Pembina Kota Tegal yang berjumlah 71 anak, dan semua populasi dijadikan responden penelitian.

Analisis bivariat yang digunakan peneliti adalah Man Whitney.
3. Hasil dan Pembahasan

a. Karakteristik responden

Tingkat Pendidikan

Pendidikan responden paling banyak adalah Perguruan Tinggi yaitu 48 responden $(67,6 \%)$.

Pengetahuan berkaitan dengan pendidikan dimana diharapkan seseorang dengan pendidikan tinggi, maka orang tersebut akan semakin luas pengetahuannya, begitu pula dalam memantau perkembangan dan pertumbuhan anaknya termasuk dalam Masalah Mental Emosional ${ }^{[9]}$.

\section{Paritas}

Tabel 1 Paritas Responden

\begin{tabular}{ccc}
\hline Paritas & Frekuensi & $(\%)$ \\
\hline 1 anak & 22 & 38,0 \\
$2-4$ anak & 44 & 62,0 \\
\hline Total & 71 & 100 \\
\hline
\end{tabular}

Karakteristik responden berdasarkan paritas, menunjukkan bahwa sebagian besar responden mempunyai 2-4 anak yaitu 44 responden $(62,0 \%)$.

Pengalaman pribadi seseorang akan berbeda, begitu pula pada cara mengasuh anak, hal ini dikarenakan kebiasaan atau anggapan responden bahwa pola asuh anak itu sama sehingga dapat dijadikan pelajaran dalam mengasuh anak yang lainnya.

\section{Pendapatan}

Hasil penelitian tentang karakteristik responden berdasarkan Pendapatan, disajikan dalam tabel berikut:

Tabel 2. Pendapatan orang tua

\begin{tabular}{ccc}
\hline Pendapatan & Frekuensi & $(\%)$ \\
\hline Sesuai UMR & 57 & 80,3 \\
Tidak Sesuai & 14 & 19,7 \\
\hline Total & 71 & 100 \\
\hline
\end{tabular}

Hasil penelitian menunjukkan bahwa pendapatan orang tua sebagian besar sesuai UMR yaitu 57 responden (80,3\%). Keluarga dengan tingkat perekonomian yang rendah kemungkinan untuk memenuhi sumber daya yang diperlukan dalam memberikan lingkungan yang aman, dan memenuhi nutrisi untuk membantu perkembangan optimal anak, akan berkurang. 


\section{Nutrisi}

Hasil penelitian tentang karakteristik responden berdasarkan nutrisi, disajikan dalam tabel di bawah ini.

Tabel 3. Distribusi Frekuensi Responden berdasarkan Nutrisi anak pra sekolah di TK Negeri Pembina Kota Tegal

\begin{tabular}{|c|c|c|}
\hline Nutrisi & Frekuensi & $(\%)$ \\
\hline Tidak Sesuai & 4 & 5,6 \\
\hline Sesuai & 67 & 94,4 \\
\hline Total & 71 & 100 \\
\hline
\end{tabular}
menunjukkan bahwa sebagian besar responden nutrisinya sudah sesuai yaitu 67 responden $(94,4 \%)$.

Nutrisi mengatur pertumbuhan pada semua tahap perkembangan, nutrisi buruk dapat mempengaruhi perkembangan ${ }^{[10]}$.

\section{Riwayat Penyakit}

Riwayat penyakit pada responden menunjukkan bahwa sebagian besar tidak mempunyai riwayat penyakit yaitu 70 responden $(98,6 \%)$. Salah satu yang dapat mempengaruhi Masalah Mental Emosional adalah riwayat penyakit.

Gangguan herediter seringkali mengganggu pertumbuhan dan perkembangan anak - anak yang terlihat pada gangguan skeletal, seperti anomaly kromosom atau dwarfisme.

Gangguan pada pencernaan yang berakibat gangguan absropsi nutrisi tubuh pada anak dapat menyebabkan efek yang merugikan pada pertumbuhan dan perkembangan anak ${ }^{[5]}$.

\section{Durasi penggunaan gadget}

Tabel 4. Durasi penggunaan gadget

\begin{tabular}{ccc}
\hline Durasi & Frekuensi & $(\%)$ \\
\hline Berlebihan & 43 & 60,6 \\
Normal & 28 & 39,4 \\
\hline Total & 71 & 100 \\
\hline Durasi & penggunaan & gadget
\end{tabular}

menunjukkan bahwa 43 anak $(60,6 \%)$ menggunakan gadget secara berlebihan atau penggunaan gadget lebih dari 1 jam per hari.

Berdasarkan sudut pandang ilmu kesehatan jiwa, pengunaan gadget pada usia dini tidak disarankan karena dapat menyebabkan anak tidak dapat belajar untuk berkomunikasi dan bersosialisasi $^{[11] \text {. }}$

Terbatasnya respon anak karena penggunaan gadget akan mengganggu perkembangan, ketidakmampuan anak untuk bergaul dan beradaptasi karena anak tidak mampu menjalin emosi, alhasil anak tidak dapat merespon hal yang ada di sekelilingnya baik secara emosi maupun verbal ${ }^{[2] .}$

Masalah Mental Emosional

Tabel 5. Masalah Mental Emosional

\begin{tabular}{ccc}
\hline $\begin{array}{c}\text { Masalah Mental } \\
\text { Emosional }\end{array}$ & Frekuensi & $\%$ \\
\hline Gangguaan & 39 & 54,9 \\
Normal & 32 & 45,1 \\
Total & 71 & 100 \\
\hline
\end{tabular}

Dari tabel 5 distribusi frekuensi masalah mental emosional menunjukkan bahwa sebagian besar 39 anak $(54,9 \%)$ mengalami gangguan Masalah Mental Emosional.

Masalah mental emosional pada anak dipengaruhi oleh beberapa faktor, salah satunya adalah type kelompok. Type ini adalah type sosial yang erat hubungannya dengan primer (keluarga), sekunder (kelompok bermain), dan tersier (hubungan antar anak-anak dalam bis dan kereta). Yang paling berpengaruh dalam masalah mental emosional adalah hubungan primer.

Pengaruh Penggunaan Gadged Terhadap Masalah Mental Emosional

Tabel 6. Pengaruh antara Durasi penggunaan Gadget Terhadap Masalah Mental Emosional pada anak pra sekolah di TK Negeri Pembina Kota Tegal

\begin{tabular}{crcccccc}
\hline \multicolumn{4}{c}{ Masalah Mental } & & & \\
Eurasi & \multicolumn{3}{c}{ Emosional } & Total & $A$ \\
Gadget & \multicolumn{2}{c}{$\mathrm{n}$. Nua } & Normal & & & \\
& $\mathrm{N}$ & $\%$ & $\mathrm{~N}$ & $\%$ & $\mathrm{~N}$ & $\%$ & \\
\hline Berlebih & 30 & 42,3 & 13 & 18,3 & 43 & 60,6 & 0,00 \\
Normal & 9 & 12,7 & 19 & 26,8 & 28 & 39,4 & 2 \\
\hline Total & 39 & 54,9 & 32 & 45,1 & 71 & 100 & \\
\hline
\end{tabular}

Berdasarkan Tabel 8 responden yang menggunakan gadget dengan durasi berlebihan sebagian besar mengalami gangguan Masalah Mental Emosional yaitu 30 responden $(42,3 \%)$, sedangkan responden yang menggunakan gadget 
dengan durasi normal sebagian besar tidak mengalami gangguan Masalah Mental Emosional yaitu 9 responden $(12,7 \%)$.

Hasil uji korelasi Mann Whitney diperoleh nilai $\alpha$ hitung 0,002 , ini artinya bahwa $\alpha$ hitung lebih kecil dari $\alpha$ tabel $(0,002<0,005)$ yang berarti Ho ditolak dan Ha diterima artinya ada pengaruh antara durasi penggunaan gadget dengan Masalah Mental Emosional pada anak pra sekolah di TK Negeri Pembina Kota Tegal.

Responden yang menggunakan gadget lebih dari 1 jam per hari maka akan mempengaruhi Masalah Mental Emosional anak. Pengunaan gadget yang berlebihan, berakibat anak tidak dapat belajar dengan cara alami bagaimana berkomunikasi dan sosialisasi. Anak juga tidak mampu mengenal emosi, alhasil anak tidak dapat merespon hal yang ada di sekelilingnya baik secara emosi maupun verbal.

Hasil penelitian ini didapatkan bahwa penggunaan gadget secara terus menerus dapat menghambat proses perkembangan psikologis anak usia dini. Apalagi jika orang tua juga membiarkan anak secara terus menerus menggunakan aplikasi gadget yang akan menjadikan anak tersebut menjadi tidak konsentrasi dalam belajar dan menurunkan kualitas anak dalam bersosialisasi karena penggunaan gadget yang sudah tidak seimbang dengan efesien penggunaannya.

Frekuensi penggunaan Gadget sangat memengaruhi perilaku komunikasi individu. Kini gadget sudah menjadi media komunikasi pokok. Hal tersebut bisa dibuktikan dengan kenyataan di lapangan. Semua orang pasti tidak bisa lepas dari gadget, baik dalam berkomunikasi ataupun sekadar mengunggah di media sosial. Hal tersebut memperlihatkan bahwa intensitas penggunaan gadget berpengaruh terhadap perubahan perilaku individu ${ }^{[4]}$.

\section{Kesimpulan}

Karakteristik responden pada penelitian ini sebagian besar berpendidikan tinggi, mempunyai anak $2-4$, berpendapatan sesuai UMR, nutrisi anak sudah sesuai dan tidak mempunyai riwayat penyakit infeksi. Penggunaan gadged pada responden berlebihan (lebih dari 1 jam), dan sebagian responden mengalami masalah mental emosional. Berdasarkan uji statistika didapatkan hasil ada pengaruh antara durasi penggunaan gadget dengan masalah mental emosional pada anak pra sekolah di TK Negeri Pembina Kota Tegal. $(\alpha=0,002<$ $0,005)$, anak yang berlebihan menggunakan gadget atau lebih dari 1 jam per hari maka akan mempengaruhi masalah mental emosional anak.

Penggunaan gadget pada anak usia pra sekolah dapat memberikan dampak yang negatif pada anak usia pra sekolah jika dilakukan secara berlebihan sehingga sebaiknya orang tua membatasi penggunaan gadget yaitu pada waktu-waktu tetentu saja dan menyarankan anak untuk bermain dengan teman sebayanya sehingga tidak mengalami gangguan perkembangan psikosial anak.

\section{Daftar Pustaka}

[1] APJII (Asosiasi Penyelenggara Jasa Internet Indonesia) pada tahun 2014. Data Penggunaan Gadget

[2] Wiguna, 2013. Mengenali dan Memahami Tumbuh Kembang Anak. Jogjakarta: Katahari

[3] Nugraha, 2013. Perkembangan Media Informasi dan Teknologi Terhadap anak. Malang: Universitas Brawijaya.

[4] Gifary, 2009. Gelombang Kejahatan Seks Remaja Modern. Bandung: Mujahid.

[5] Hidayat, 2005. Pengantar Ilmu Kesehatan Anak untuk Pendidikan Kebidanan. Jakarta: Salemba Merdeka

[6] Dinas Kesehatan Jawa Tengah, 2014. Profil Kesehatan Jawa Tengah 2014. Semarang: Dinkes Jateng

[7] Nursalam, 2008. Konsep dan Penerapan Metodologi Penelitian Ilmu Keperawatan. Jakarta : Salemba Medika 
[8] Notoadmodjo, 2010. Metodologi Penelitian. Jakarta: PT. Rineka Cipta

[9] Pengestu, 2014. Statistik Induktif. Yogyakarta: BPF.

[10] Soetjiningsih, 2002. Tumbuh Kembang Anak. Jakarta: EGC

[11] Hidayahti. 2013. Pengaruh Penggunaan Gadget Terhadap Perkembangan Psikologis Anak Usia Dini. Skripsi 